\title{
Wound Healing Related Biological Activities and Chemical Composition of Absolute from Hemistepta lyrata Bunge Flower
}

\author{
D. I. HWANG, K. J. WON¹, D. Y. KIM², H. B. KIM, Y. LI, S. M. PARK, I. H. CHOI AND H. M. LEE* \\ Department of Cosmetic Science, College of Life and Health Sciences, Hoseo University, Asan 31499, ${ }^{1}$ Departments of \\ Physiology, School of Medicine, Konkuk University, Seoul 05029, Republic of Korea, ${ }^{2}$ College of Chemistry and Chemical \\ Engineering, Hunan Institute of Science and Technology, Yueyang, Hunan 414006, China
}

Hwang et al.: Keratinocyte proliferation and migration by Hemistepta lyrata

\begin{abstract}
The Hemistepta lyrata Bunge flower has various biological and pharmacological effects, but effects of its absolute on skin regeneration or wound healing-linked responses remain unknown. In the present study, effects of Hemistepta lyrata Bunge flower absolute were explored on the proliferation and migration of normal human keratinocytes as well as the composition of absolute from Hemistepta lyrata Bunge flower was analysed using gas chromatography-mass spectrometry. Hemistepta lyrata Bunge flower absolute stimulated both proliferation and migration of the keratinocytes. It also enhanced the phosphorylation of extracellular signal-regulated kinase $1 / 2$ and serine/threonine-specific protein kinase in human keratinocytes. Moreover, the Hemistepta lyrata Bunge flower absolute increased the sprout outgrowth of human keratinocytes. Gas chromatography-mass spectrometry analysis of Hemistepta lyrata Bunge flower absolute allowed identification of 16 compounds. These findings indicated that the absolute promoted the migration and proliferation of keratinocytes. Therefore, Hemistepta lyrata Bunge flower absolute might play a beneficial role in skin regeneration or wound healing by elevating migration and proliferation of keratinocytes.
\end{abstract}

Key words: Hemistepta lyrata Bunge, keratinocyte, proliferation, migration, skin barrier

Keratinocytes are the main cells of the epidermis ${ }^{[1]}$, producing a variety of molecules such as epidermal growth factor (EGF), transforming growth factors- $\beta$ (TGF- $\beta$ ), and interleukins, which exert proinflammatory and immune responses as well as promote wound healing and epithelialization ${ }^{[2,3]}$. Proliferation and migration of keratinocytes are important events in re-epithelialization, skin regeneration and wound healing for various skin injuries ${ }^{[4-6]}$. Moreover, epidermal keratinocyte migration and proliferation are mediated by intracellular kinase signalling pathways such as extracellular signalling-regulated kinase (Erk) $1 / 2$ and serine/threonine-specific protein kinase $(\mathrm{Akt})^{[7,8]}$. These molecules participate in migration and proliferation in keratinocytes, activated by growth factors including EGF and TGF- $\beta^{[7,9]}$. In addition, our previous study has reported that Erk $1 / 2$ and Akt activation are associated with the migration and proliferation of keratinocytes ${ }^{[10]}$.

Hemistepta lyrata Bunge (HLB), family Asteraceae, is widely distributed in East Asian countries such as

This is an open access article distributed under the terms of the Creative Commons Attribution-NonCommercial-ShareAlike 3.0 License, which allows others to remix, tweak, and build upon the work non-commercially, as long as the author is credited and the new creations are licensed under the identical terms

Accepted 19 March 2019

Revised 23 October 2018

Received 07 March 2018

Indian J Pharm Sci 2019;81(3):544-550 
Korea, Japan, and China ${ }^{[11,12]}$. This plant is used as traditional herbal remedies for treating inflammation, fever, haemorrhage, bacterial infections, tumours and haemorrhoids, and is also a source for food salads ${ }^{[13,14]}$. However, there is no research on the absolute extracted from the HLB flower (HLBF), especially on keratinocyte proliferation and migration linked to skin regeneration.

In this study, the absolute from HLBF was prepared by solvent extraction (absolute $)^{[10]}$. To investigate its possible role in skin regeneration, the effects of the absolute on migration and proliferation of human epidermal-keratinocytes were studied. The chemical constituents of HLBF absolute were explored using gas chromatography-mass spectrometry (GC/MS).

Dulbecco's modified eagle medium (DMEM), fetal bovine serum (FBS), phosphate-buffered saline (PBS), and penicillin/streptomycin $(\mathrm{P} / \mathrm{S})$ were purchased from either Hyclone (Logan, Utah, USA) or Invitrogen (Carlsbad, CA, USA). EGF was purchased from R\&D Systems (Minneapolis, MN, USA). The bovine serum albumin (BSA) was procured from Sigma-Aldrich (St. Louis, MO, USA) and the EZ-CyTox kit from Daeil Lab Service (Seoul, South Korea). The antibodies used were antiphospho-Akt (p-Akt), antiAkt, antiphosphoErk 1/2 (p-Erk 1/2) and antiErk 1/2 (Cell Signaling, Beverly, MA, USA), and anti $\beta$-actin (Sigma-Aldrich).

HLBF was obtained from Hoseo University, Asan city, Chungnam, South Korea and was identified in the Division of Forest Biodiversity and Herbarium, Korea National Arboretum, Korea. A voucher specimen (no. HLBF Ab-001) was deposited at the Herbarium of the College of Life and Health Science, Hoseo University. The absolute was extracted from HLBF using solvent extraction $^{[10]}$ as described here. Fresh flowers (2 kg) were kept in contact with n-hexane by complete immersion for $1 \mathrm{~h}$ at room temperature. Solvent removal in a rotary evaporator in vacuo at $25^{\circ}$ produced a deep yellow waxy residue (concrete) constituting the combined extracts. The concrete was treated by mixing with $500 \mathrm{ml}$ of ethanol (99\%) and incubated at $-20^{\circ}$ overnight. Filtration through a sintered funnel and evaporation of ethanol at $35^{\circ}$ led to the formation of a light yellow dewaxed absolute. Finally, $1.5 \mathrm{ml}$ of absolute (v/w, $0.075 \%$ ) was obtained from the HLBF. The composition of the HLBF absolute was identified by GC/MS.

Components of HLBF absolute were analysed at the Korean Basic Science Institute (Seoul, Korea), and identified using GC/MS analysisperformed on anAgilent 6890N GC/5975i MS instrument (Palo Alto, California, USA) and DB5-MS capillary column $(30 \mathrm{~m} \times 250 \mu \mathrm{m}$, $0.25 \mu \mathrm{m}$ film thickness). The carrier gas used was helium at a flow rate of $1 \mathrm{ml} / \mathrm{min}$. The injector port and interface temperatures were $280^{\circ}$ and $300^{\circ}$, respectively. The gas chromatography oven was kept at $40^{\circ}$ for $2 \mathrm{~min}$, after which it was increased to $230^{\circ}$ at a rate of $5^{\circ} / \mathrm{min}$, and then kept constant at $300^{\circ}$ for $5 \mathrm{~min}$. The split ratio was $1: 10$. The mass ranges were from $\mathrm{m} / \mathrm{z}$ 40-800. The retention indices (RI) for all compounds were determined according to the Kovats method ${ }^{[15]}$ using standard $\mathrm{C}_{7}-\mathrm{C}_{40}$ n-alkanes. The compounds were identified by comparing their RI with Kovats indices, and by matching their fragmentation patterns in the mass spectra with those of the Wiley7NIST0.5L Mass Spectral library and catalogues for mass spectra. GC/ MS data were reanalysed by comparison their RI with data in the literature ${ }^{[16-22]}$.

The human keratinocyte cell line (HaCat) was obtained from National Development Institute of Korean Medicine (Gyeongsan, Gyeongbuk, South Korea). HaCats were cultured in DMEM medium supplemented with $10 \%$ FBS and $1 \% \mathrm{P} / \mathrm{S}$ solution. The cells were incubated in a $95 \%$ humidified atmosphere with $5 \%$ $\mathrm{CO}_{2}$ at $37^{\circ}$. For all experiments, the cells were grown to $70-80 \%$ confluence before use.

Proliferation of HaCat cells was measured using the EZ-CyTox $\mathrm{kit}^{[10]}$. HaCat cells were seeded into 96well microtiter plates at a density of $2 \times 10^{3}$ cells/well and exposed to varying concentrations $(0.1-100 \mu \mathrm{g} / \mathrm{ml})$ of HLBF absolute (dissolved and diluted in DMEM containing $0.5 \% \mathrm{DMSO}$ ) for $48 \mathrm{~h}$. The cells were then incubated with $10 \mu \mathrm{l}$ of EZ-CyTox reagent for $30 \mathrm{~min}$ at $37^{\circ}$. Cell proliferation levels were measured using an ELISA reader (Synergy 2, Bio-Tek Instruments, Winooski, VA, USA) at $450 \mathrm{~nm}$.

Migration assay was performed in 48-well Boyden micro chemotaxis chamber (Neuro Probe Inc., Gaithersberg, MD, USA) as previously described ${ }^{[10]}$. The lower chamber wells were loaded with various concentrations of HLBF absolute in medium containing $0.1 \%$ BSA. The medium of lower wells was overlaid with a membrane, and the upper wells were loaded with HaCat cells $\left(5 \times 10^{4}\right.$ cells $\left./ 50 \mu \mathrm{l}\right)$ in medium containing $0.1 \%$ BSA. The chambers were then incubated at $37^{\circ}$ for $3 \mathrm{~h}$. The membrane was fixed and stained using Diff-Quik (Baxter Healthcare, Miami, FL, USA). The number of cells migrating through the membrane was counted using a light microscope. 
Total proteins $(50 \mu \mathrm{g} /$ lane $)$ were separated using sodium dodecyl sulphate-polyacrylamide gel electrophoresis on $10 \%$ acrylamide gels. The proteins were then transferred on to a polyvinylidene difluoride membrane (Roche, Indianapolis, IN, USA) at $4^{\circ}$, which was then blocked with PBS containing $3 \%$ non-fat dry milk, for $2 \mathrm{~h}$ at the room temperature. Subsequently, the membrane was washed using PBS containing $0.05 \%$ Tween 20, followed by incubation with Akt, p-Akt, Erk $1 / 2$, p-Erk $1 / 2$, and $\beta$-actin antibodies (1:1000-10 000 dilutions). The immune-reactive bands were visualized using a chemiluminescent substrate.

The ex vivo migration and proliferation of HaCat cells were measured by a collagen sprout assay ${ }^{[10]}$. A dot in a plate was made using $\mathrm{HaCat}$ cells $\left(7.5 \times 10^{4}\right.$ cells $\left./ \mathrm{ml}\right)$ mixed with type I collagen, $10 \times \mathrm{DMEM}$, and $1 \mathrm{~N} \mathrm{NaOH}$ ( $\mathrm{pH}$ 7.2). After drying, the spots were treated with or without HLBF absolute, and incubated at $37^{\circ}$. After $72 \mathrm{~h}$, the spots were fixed and stained using Diff-Quik. Images of the spot were obtained and photographed using light microscopy $(\times 100)$, and the lengths of the sprouts were analysed using the Scion Image software (Frederick, Maryland, USA).

Data were expressed as the mean \pm standard error of the mean of the indicated number of experiments. Statistical analysis of the data was performed using Student's t tests for comparisons between pairs of groups, and by ANOVA for multiple comparisons. $P$ values less than 0.05 were considered to be significantly different.

\section{a}

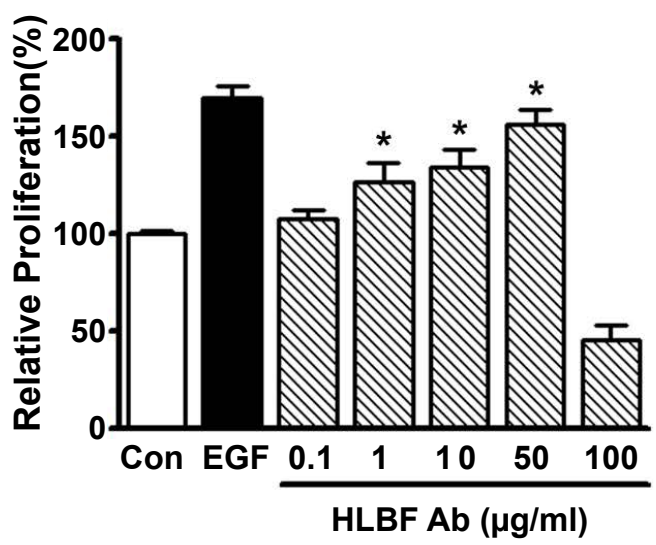

HLBF absolute induced proliferation of keratinocytes in a concentration-dependent manner, in the range of $0.1-50 \mu \mathrm{g} / \mathrm{ml}$. This response was maximum at $50 \mu \mathrm{g} / \mathrm{ml}(156.3 \pm 7.5 \%$ of control), at a level similar

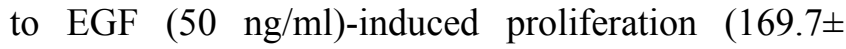
$6.4 \%$ of control, fig. $1 \mathrm{a} ; \mathrm{n}=5$ ). However, treatment with HLBF absolute at a higher concentration $(100 \mu \mathrm{g} / \mathrm{ml})$ resulted in a reduction of keratinocyte proliferation as compared to the untreated control group (fig. 1a; $\mathrm{n}=5$ ). These data indicated that HLBF absolute exerted a positive effect on the proliferation of keratinocytes in the concentration range of $0.1-50 \mu \mathrm{g} / \mathrm{ml}$, but was cytotoxic at higher concentrations $(100 \mu \mathrm{g} / \mathrm{ml})$.

In addition, HLBF absolute $(0.1-100 \mu \mathrm{g} / \mathrm{ml})$ also increased keratinocyte migration in a concentrationdependent manner in the concentration range 0.1 $50 \mu \mathrm{g} / \mathrm{ml}$, with significant migration observed at $10(147.1 \pm 7.4 \%$ of control $)$ and $50 \mu \mathrm{g} / \mathrm{ml}(158.1 \pm 8.6 \%$ of control), but the migration at these 2 concentrations was lower compared to $5 \mathrm{ng} / \mathrm{ml}$ EGF-induced migration ( $365.5 \pm 26.8 \%$ of control; fig. $1 \mathrm{~b} ; \mathrm{n}=4$ ). On the other hand, treatment with HLBF absolute at $100 \mu \mathrm{g} / \mathrm{ml}$ had no effect on keratinocyte migration, implying that this response may be caused by cytotoxicity (fig. $1 \mathrm{~b} ; \mathrm{n}=4$ ).

The epidermis of the skin comprises of keratinocytes ${ }^{[1]}$, which play crucial roles in skin regeneration due to their properties of proliferation and migration ${ }^{[7]}$. The wound healing process is associated with rapid migration and proliferation of keratinocytes ${ }^{[23]}$.

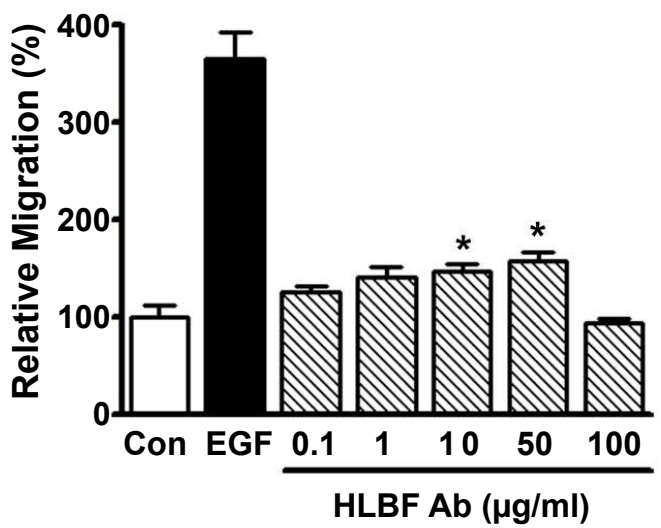

Fig. 1: Effects of HLBF absolute on proliferation and migration of HaCat cells

(a) HaCat cells were incubated in the presence or absence of Hemistepta lyrata Bunge flower (HLBF) absolute (0.1-100 $\mu \mathrm{g} / \mathrm{ml})$ for $48 \mathrm{~h}$ to evaluate proliferation using the XTT assay. Proliferation of cells in the quiescent state was considered as $100 \%(\mathrm{n}=5)$. Black bar indicates the response of positive control, recombinant human epidermal growth factor (EGF; $50 \mathrm{ng} / \mathrm{ml})$. *P<0.05 vs. the quiescent state. (b) HaCat cells were incubated in the presence or absence of HLBF absolute $(0.1-100 \mu \mathrm{g} / \mathrm{ml})$ for $3 \mathrm{~h}$ to perform migration analysis using a Boyden chamber assay. Migration of cells in the quiescent state was considered as $100 \%(n=4)$. Black bar indicates the response of the positive control EGF $(5 \mathrm{ng} / \mathrm{ml}) . * P<0.05$ vs. the quiescent state 
Therefore, these findings suggest that keratinocyte migration and proliferation induced by HLBF absolute could potentially cause skin regeneration leading to wound healing.

Erk1/2 and Akt proteins have reported to be linked to the proliferation and migration signalling pathways in keratinocytes ${ }^{[7,8]}$, indicating that these kinases might be involved in mediating the effects of HLBF absolute on proliferation and migration of keratinocytes. To explore this possibility, the effects of HLBF absolute on Erk $1 / 2$ and Akt phosphorylation in keratinocytes was studied. HLBF absolute $(0.1-100 \mu \mathrm{g} / \mathrm{ml})$ increased the phosphorylation of Erk1/2 in keratinocytes in a concentration-dependent manner in the concentration range of 0.1 to $50 \mu \mathrm{g} / \mathrm{ml}$, with significant upregulation at $10(170.7 \pm 8.0 \%$ of control $)$ and $50 \mu \mathrm{g} / \mathrm{ml}(288.9 \pm$ $35.4 \%$ of control), but not at $100 \mu \mathrm{g} / \mathrm{ml}$ (fig. $2 \mathrm{a}$ and b; $\mathrm{n}=4)$. Moreover, HLBF absolute $(0.1-100 \mu \mathrm{g} / \mathrm{ml})$ also induced phosphorylation of Akt in keratinocytes in the concentration range of 10 to $100 \mu \mathrm{g} / \mathrm{ml}$ with the maximum effect at $50 \mu \mathrm{g} / \mathrm{ml}(236.2 \pm 22.3 \%$ of control), which was found similar to that of $5 \mathrm{ng} / \mathrm{ml}$ EGF induced Akt phosphorylation $(244.1 \pm 14.7 \%$ of control, fig. $2 \mathrm{a}$ and $c ; n=4)$. From these results, it could be inferred that the HLBF absolute-induced proliferation and migration of keratinocytes is mediated by the Erk 1/2 and/or Akt pathways.

To confirm the effects of HLBF absolute on both proliferation and migration in keratinocytes, ex vivo sprouting assay was performed on keratinocyte spots treated with or without HLBF absolute ( 1 and $50 \mu \mathrm{g} / \mathrm{ml}$ ). Treatment with $50 \mu \mathrm{g} / \mathrm{ml}$ HLBF absolute significantly increased the sprout growth in keratinocytes ( $274.5 \pm 34.6 \%$ of control; $n=4$; fig. 3 ). This increased level was lower compared to that induced by $50 \mathrm{ng} / \mathrm{ml}$ EGF (440.7 $\pm 39.7 \%$ of control; $n=4$; fig. 3 ). Since the ex vivo sprouting assay is useful for assessing both proliferation and migration in various cell types ${ }^{[10,24]}$,

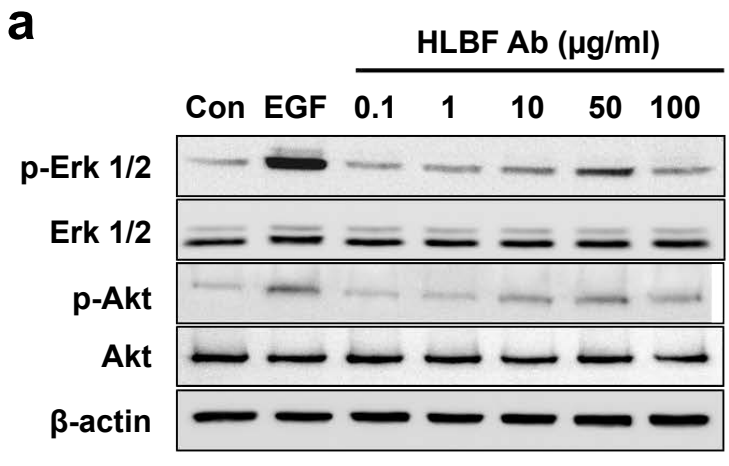

b

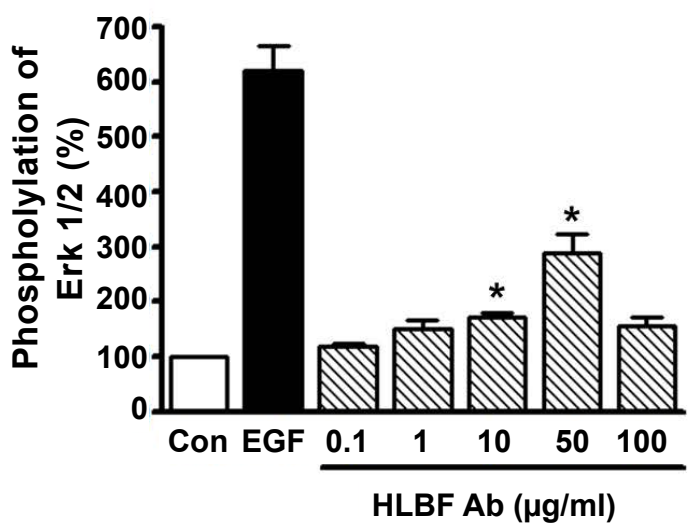

C

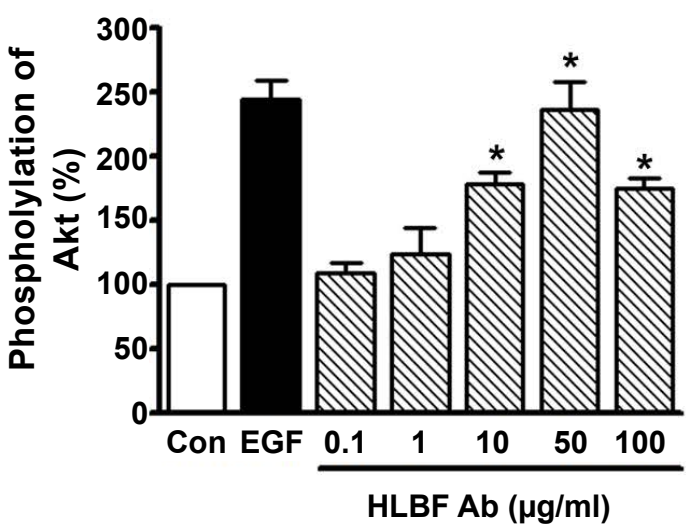

Fig. 2: Effect of HLBF absolute on phosphorylation of kinases in HaCat cells

(a) Representative images showing phosphorylation of MAPKs in HaCat cells. HaCat cells were incubated for 10 min with or without Hemistepta lyrata Bunge flower (HLBF) absolute $(0.1-100 \mu \mathrm{g} / \mathrm{ml})$. The cell lysates obtained were immunoblotted with antibodies against the indicated kinases $(n=4)$. Erk1/2 and Akt phosphorylation were evaluated with phospho-specific antibodies. The total expression of kinases and $\beta$-actin were measured with nonphospho-specific and anti- $\beta$-actin antibody, respectively. Recombinant human epidermal growth factor (EGF, $5 \mathrm{ng} / \mathrm{ml}$ ) was used as a positive control. (b and c) The statistical graph of Erk 1/2 (b) and Akt phosphorylation level (c) obtained from panel a. Phosphorylation level in the quiescent state was considered as $100 \%$. $* P<0.05$ vs. the quiescent state. p-Erk1/2, phosphorylated Erk1/2; p-Akt, phosphorylated Akt 
the results from the assay indicated that HLBF absolute stimulated keratinocyte migration and proliferation, thus indicating a possible positive role of HLBF absolute in skin regeneration or wound healing.

To identify the major constituents of HLBF absolute, $\mathrm{GC} / \mathrm{MS}$ analysis was performed. GC/MS analysis of the

a

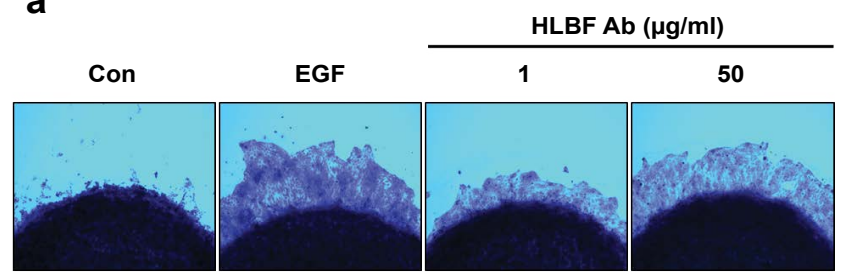

b

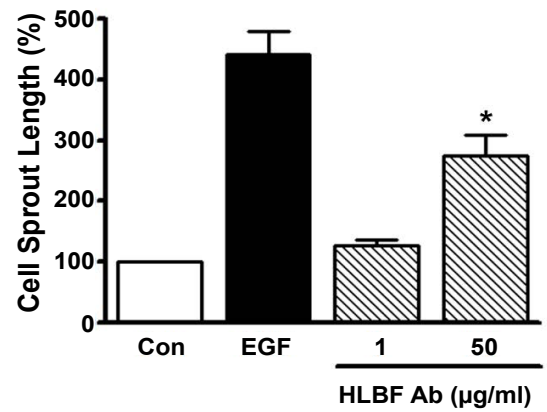

Fig. 3: Effect of HLBF absolute on the sprout formation of HaCat cells

(a) Representative images showing the change of sprout formation in HaCat cells. HaCat cells mixed with collagen were dropped on a 24-well plate, and incubated in the presence or absence of Hemistepta lyrata Bunge flower (HLBF) absolute (1 and $50 \mu \mathrm{g} / \mathrm{ml}$ ) for $72 \mathrm{~h}$. (b) The statistical graph obtained from panel a. The value in the quiescent state was expressed as $100 \%(n=4)$. Recombinant human epidermal growth factor (EGF, $50 \mathrm{ng} / \mathrm{ml}$ ) was used as a positive control. ${ }^{*} \mathrm{P}<0.05$ vs. the quiescent state
HLBF absolute showed peaks indicating the presence of 16 phytochemical compounds listed in Table 1 (fig. 4). Among the 16 identified, compounds with high area were $\alpha$-amyrin (15.8\%), $\beta$-amyrin $(15.0 \%)$, 1-pentadecene $(8.7 \%)$, methyl salicylate $(8.2 \%)$, tricosane $(7.7 \%)$, ethyl linolenate $(7.3 \%)$. Of these compounds, $\alpha$-amyrin and palmitic acid, but not the others, were reported to stimulate proliferation of keratinocytes ${ }^{[25,26]}$, implying that HLBF absolute could induce keratinocyte proliferation. Moreover, whether

TABLE 1: COMPONENTS OF HEMISTEPTA LYRATA BUNGE FLOWER ABSOLUTE

\begin{tabular}{|c|c|c|c|c|}
\hline \multirow{2}{*}{$\begin{array}{l}\text { Compound } \\
\text { Name }\end{array}$} & \multicolumn{2}{|c|}{$\mathbf{R} \mathbf{I}^{\mathrm{a}}$} & $\begin{array}{l}\text { Retention } \\
\text { time }\end{array}$ & $\begin{array}{c}\text { Area } \\
(\%)\end{array}$ \\
\hline & \multicolumn{2}{|c|}{ Observed Literature } & & \\
\hline $\begin{array}{l}\text { Methyl } \\
\text { salicylate }\end{array}$ & 1188 & $1190^{[16]}$ & 27.2 & 8.2 \\
\hline Tridecane & 1300 & $1299^{[16]}$ & 34.7 & 4.1 \\
\hline B-Caryophyllene & 1461 & $1467^{[17]}$ & 41.8 & 7.2 \\
\hline Germacrene D & 1472 & $1480^{[16]}$ & 45.6 & 4.8 \\
\hline 1-Pentadecene & 1493 & - & 46.9 & 8.7 \\
\hline 1-Heptadecene & 1693 & $1690^{[18]}$ & 58.3 & 2.2 \\
\hline $\begin{array}{l}\text { Benzyl } \\
\text { salicylate }\end{array}$ & 1857 & $1863^{[16]}$ & 66.9 & 1.9 \\
\hline Palmitic acid & 1967 & $1984^{[19]}$ & 72.3 & 3.8 \\
\hline Heneicosane & 2101 & $2100^{[16]}$ & 78.5 & 4.6 \\
\hline Ethyl linolenate & 2142 & $2145^{[20]}$ & 80.3 & 7.3 \\
\hline Tricosane & 2301 & $2300^{[16]}$ & 87.2 & 7.7 \\
\hline Erucyl alcohol & 2428 & - & 92.3 & 1.8 \\
\hline $\begin{array}{l}\text { Methyl } \\
\text { docosanoate }\end{array}$ & 2527 & - & 96.2 & 4.3 \\
\hline Nonacosane & 2902 & $2900^{[21]}$ & 104.6 & 2.5 \\
\hline B-Amyrin & 3332 & $3337^{[22]}$ & 111.0 & 15.0 \\
\hline a-Amyrin & 3380 & - & 111.8 & 15.8 \\
\hline Total (\%) & & & & 100.00 \\
\hline
\end{tabular}

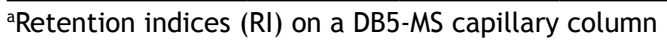

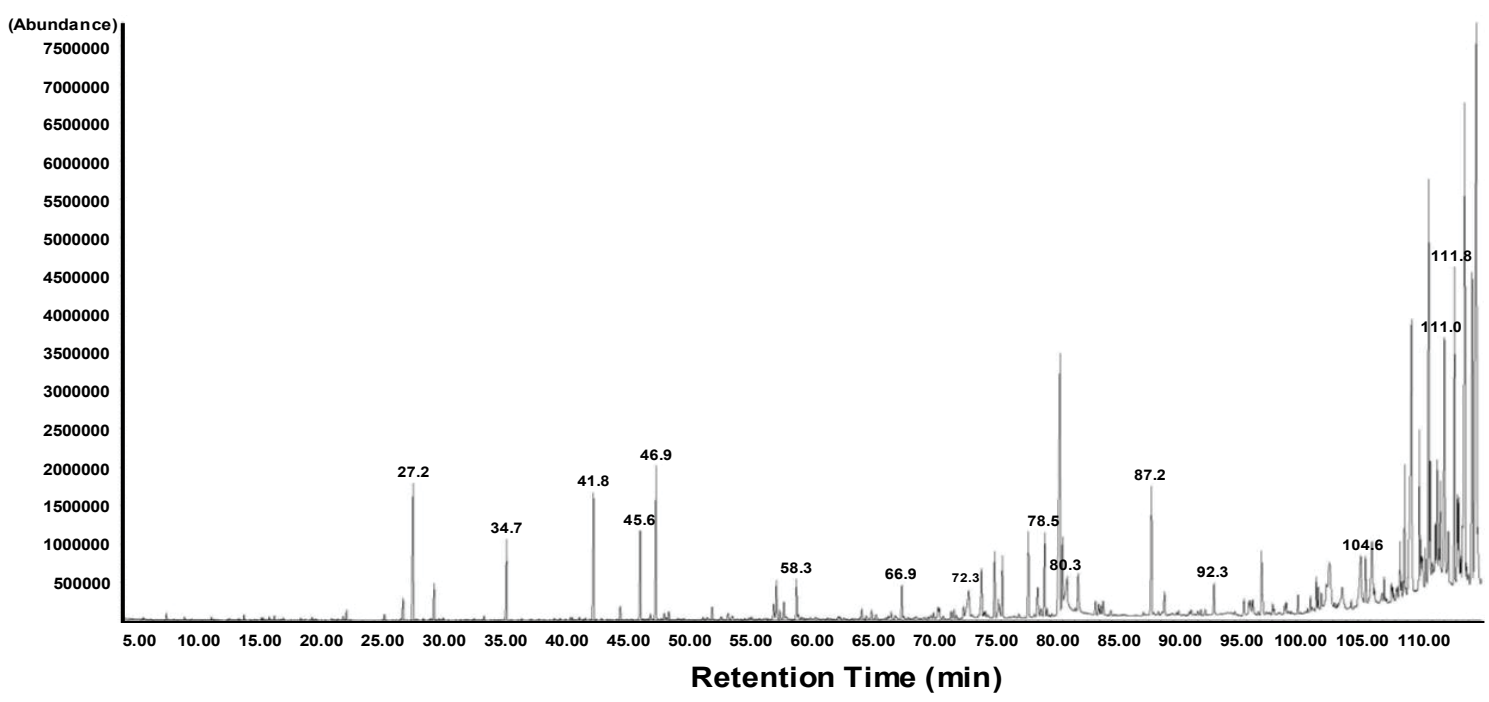

Fig. 4: GC/MS total ion chromatogram of HLBF absolute showing major compound peaks

The numbers in each peak indicate the retention times of peaks to correspond to the identified 16 compounds listed in Table 1 
any of these compounds identified would have affected keratinocyte migration is not known. Therefore, it is possible to suggest that some or all of these identified compounds could have been responsible for the effects of HLBF absolute on keratinocyte proliferation and migration leading to skin regeneration and wound healing ${ }^{[4-6]}$, although the effects of these components alone were not tested.

In conclusion, the present study demonstrated that HLBF absolute promoted proliferation and migration of keratinocytes, probably via the Erk $1 / 2$ or Akt pathway. Moreover, HLBF absolute induced sprout growth in keratinocytes. Therefore, it is possible to conclude that HLBF absolute can be used to promote skin regeneration and wound healing. This study provided new information that would support development of cosmetic materials for wound healing or skin beautification. Furthermore, isolation and identification of key active constituents of HLBF absolute responsible for stimulating proliferation and migration activity in keratinocytes would be important for understanding these activities of HLBF absolute.

\section{Acknowledgements:}

This study was supported by R\&D Program for Forestry Technology (Project No.2017032B10-1719BA01) provided by Korea Forest Service. Authors wish to thank Mr. Jong-Cheol Yang, Division of Forest Biodiversity and Herbarium, Korea National Arboretum, Korea for identifying the plant material.

\section{Conflicts of interest:}

The authors declare that there is no conflict of interest.

\section{REFERENCES}

1. Martin MT, Vulin A, Hendry JH. Human epidermal stem cells: Role in adverse skin reactions and carcinogenesis from radiation. Mutat Res 2016;770:349-68.

2. Feliciani C, Gupta AK, Saucier DN. Keratinocytes and cytokine/growth factors. Crit Rev Oral Bio Med 1996;7:30018.

3. Li J, Chen J, Kirsner R. Pathophysiology of acute wound healing. Clin Dermatol 2007;25:9-18.

4. Tuan TL, Keller LC, Sun D, Nimni ME, Cheung D. Dermal fibroblasts activate keratinocyte outgrowth on collagen gels. J Cell Sci 1994;107:2285-9.

5. O'Toole EA. Extracellular matrix and keratinocyte migration. Clin Exp Dermatol 2001;26:525-30.

6. Xue M, Thompson P, Kelso I, Jackson C. Activated protein C stimulates proliferation, migration and wound closure, inhibits apoptosis and upregulates MMP-2 activity in cultured human keratinocytes. Exp Cell Res 2004;299:119-27.
7. Haase I, Evans R, Pofahl R, Watt FM. Regulation of keratinocyte shape, migration and wound epithelialization by IGF-1- and EGF-dependent signaling pathways. J Cell Sci 2003;116:3227-38.

8. Schüppel M, Kürschner U, Kleuser U, Schäfer-Korting M, Kleuser B. Sphingosine 1-phosphate restrains insulin-mediated keratinocyte proliferation via inhibition of Akt through the S1P2 receptor subtype. J Invest Dermatol 2008;128:1747-56.

9. Santoro MM, Gaudino G. Cellular and molecular facets of keratinocyte reepithelization during wound healing. Exp Cell Res 2005;304:274-86.

10. Kim DY, Won KJ, Hwang DI, Yoon SW, Lee SJ, Park JH, et al. Potential skin regeneration activity and chemical composition of absolute from Pueraria thunbergiana flower. Nat Prod Commun 2015;10:2009-12.

11. Gao X, Li M, Gao Z, Li C, Sun Z. Allelopathic effects of Hemistepta lyrata on the germination and growth of wheat, sorghum, cucumber, rape, and radish seeds. Weed Biol Manag 2009;9:243-9.

12. Nugroho A, Lim SC, Byeon JS, Choi JS, Park HJ. Simultaneous quantification and validation of caffeoylquinic acids and flavonoids in Hemistepta lyrata and peroxynitrite-scavenging activity. J Pharm Biomed Anal 2013;76:139-44.

13. Encyclopaedia of the Traditional Chinese Materia Medica. Shanghai, P. R. China: Peoples Press; 1977. p. 1458-9.

14. Ha TJ, Hwang SW, Jung HJ, Park KH, Yang MS. Apigenin, tyrosinase inhibitor isolated from the flowers of Hemisteptia lyrata Bunge. J Appl Biol Chem 2002;45:170-2.

15. Kovats ES. Gas chromatographic characterization of organic substances in the retention index system. Adv Chromatogr 1965;1:229-47.

16. Adams RP. Identification of essential oil components by gas chromatography/ mass spectroscopy. Carol Stream, Illinois: Allured Publishing Co.; 1995.

17. Högnadóttir A, Rouseff RL. Identification of aroma active compounds in orange essence oil using gas chromatography - olfactometry and gas chromatography-mass spectrometry. J Chromatogr A 2003;998:201-11.

18. Binder RG, Benson ME, Flath RA. Volatile components of safflower. J Agr Food Chem 1990;38:1245-8.

19. Priestap HA, Van Baren CM, Di Leo Lira P, Coussio JD, Bandoni AL. Volatile constituents of Aristolochia argentina. Phytochemistry 2003;63:221-5.

20. Pino JA, Mesa J, Munoz Y, Marti MP, Marbot R. Volatile components from mango (Mangifera indica L.) cultivars. J Agric Food Chem 2005;53:2213-23.

21. Kaib M, Jmhasly P, Wilfert L, Durka W, Franke S, Francke $\mathrm{W}$, et al. Cuticular hydrocarbons and aggression in the termite Macrotermes subhyalinus. J Chem Ecol 2004:30:365-85.

22. Todua NG. Retention data. NIST Mass Spectrometry Data Center; 2011. Available from: https://chemdata.nist.gov/ dokuwiki/doku.php?id=start.

23. Seeger MA, Paller AS. The roles of growth factors in keratinocyte migration. Adv Wound Care (New Rochelle) 2015;4:213-24.

24. Lee CK, Lee HM, Kim HJ, Park HJ, Won KJ, Roh HY, et al. Syk contributes to PDGF-BB-mediated migration of rat aortic smooth muscle cells via MAPK pathways. Cardiovasc Res 2007;74:159-68. 
25. Biskup E, Gołębiowski M, Gniadecki R, Stepnowski P, Łojkowska E. Triterpenoid $\alpha$-amyrin stimulates proliferation of human keratinocytes but does not protect them against UVB damage. Acta Biochim Pol 2012;59:255-60.
26. Zhou BR, Zhang JA, Zhang Q, Permatasari F, Xu Y, Wu D, et al. Palmitic acid induces production of proinflammatory cytokines interleukin- 6 , interleukin- $1 \beta$, and tumor necrosis factor- $\alpha$ via a NF- $\kappa$ B-dependent mechanism in HaCaT keratinocytes. Mediators Inflamm 2013;2013:530429. 